\title{
Dental Fluorosis- Revisited
}

\author{
Abhimanyu Mohanta*1 and Prafulla K Mohanty ${ }^{2}$ \\ ${ }^{1}$ Biju Pattnaik Clollege, Mayurbhanj, India \\ ${ }^{2}$ Department of Zoology, Utkal University, India
}

Received: January 06, 2018; Published: January 17, 2018

*Corresponding author: Abhimanyu Mohanta, Biju Pattnaik Clollege, Singda, Mayurbhanj, Odisha, India- 757039, Email: amohanta01@gmail.com

\begin{abstract}
Dental fluorosis is a chronic fluoride -induced condition in which an excess of fluoride is incorporated in the developing tooth enamel and disrupt the enamel formation of the tooth. Prevalence of dental fluorosis due to high levels of fluoride in drinking water is an endemic global problem. Although, definite mechanism of dental flourosis is yet to be confirmed, hypomineralization of teeth enamel is the real fact and so the teeth enamel become more porous and softer than the normal counterparts. More exposure to the fluoride, greater is the rate of dental fluorosis. Also, children with mild dental fluorosis had lower IQ than those without dental fluorosis demands further investigation.
\end{abstract}

Keywords: Fluorosis; Endemic; Enamel; Ameloblast; Intelligent Quotient (IQ)

\section{Introduction}

Dental fluorosis is one of the growing dental public health problems in many parts of the globe. Prevalence of dental fluorosis seems to be increasing in populations especially those with high levels of fluoride in drinking water. It is more common in hilly areas where natural existence of fluoride is dominant [1]. Dental fluorosis is a chronic fluoride -induced condition in which an excess of fluoride is incorporated in the developing tooth enamel and disrupt the enamel formation of the tooth. Children in the age group of 0 to 12 years are the most prone to fluorosis as their body tissues are in formative growth stage during this period [2]. Being an anti-cariogenic agent, fluoride has been used in tooth paste, mouth wash, chewing gum, and some prescribed diet to treat dental caries. However, cumulative exposures to these things are reported to enhance the dental fluorosis [3]. In the present review, pathophysiological aspect of endemic dental fluorosis and its association with the intelligent quotient (IQ) of the children were briefly highlighted.

\section{Methodology}

Clinical, experimental, and review reports were searched in a number of bibliographic databases for scientific literature, using the search phrase "dental fluorosis', 'epidemiology of dental fluorosis' and 'dental fluorosis and IQ'."

\section{Epidemiology}

Due to the universal presence of fluoride in water, soil and the atmosphere it is not surprising that humans are exposed to various levels of fluoride intake, not only through food and water, but in industrial and pharmaceutical products and other sources.
Water-borne fluoride, however, has been said to represent the largest single component of this element's daily intake, except where unusual dietary patterns exist. World Health Organization (WHO) has recommended that the permissible limit of fluoride concentration in drinking water is $1.5 \mathrm{mg} / \mathrm{l}$. Dental fluorosis is an acute, chronic and endemic problem worldwide (Figure 1). Epidemiological studies on fluorosis have been reported from various regions of the world including Africa [4-7], Saudi Arab [8,9], India [10], China [11], Pakistan [12], Tanzania [13], Brazil [14], Kenya [15] Taiwan [16], and Malawi [17]. Chinese data on endemic fluorosis from 1990 to 2000 indicate that the state of the fluorosis had been well under control during these ten years. The prevalence of water based fluorosis in Huabei, Huadong and Xibei was declining, while the prevalence of fluorosis in Dongbei was increasing. Also the non-water-based fluorosis was reported to have been rising in west China [18]. Recently, Siddiqui et al. have reviewed and reported that mild to very mild fluorosis are very dominant in Saudi Arabian population except in Riyadh where severe fluorosis was also experienced by many [19].

Under National Oral Health Survey \& Fluoride Mapping 2002-2003, almost 19 states and Union Territories of India were covered and are reported to be highly affected with endemic fluorosis (Figure 2). High incidence of endemic fluorosis in India is due to the fact that large areas of the country contain high level of fluoride in the drinking water sources [20]. By way of multiple epidemiological studies, Dean and Elvove have established the fact that there was a close link between dental fluorosis and excessive fluoride in the drinking water. They have concluded that fluoride at the level of $1 \mathrm{ppm}$ in the drinking water would no doubt reduce 
dental caries, but having minimal detrimental effects with dental fluorosis $[21,22]$. Besides the fluoride in the drinking water, factors such as temperature [23-25], altitude of residence [26,27], diet and nutrition [28,29], and dental products [30-32] have been reported to influence dental fluorosis. It has been well observed that some children swallow more fluoride from toothpaste alone than is recommended from all sources combined. Ingesting toothpaste during childhood is a major risk factor for dental fluorosis, and can also cause symptoms of acute fluoride toxicity (e.g., nausea, vomiting and stomach pain, etc) [33].

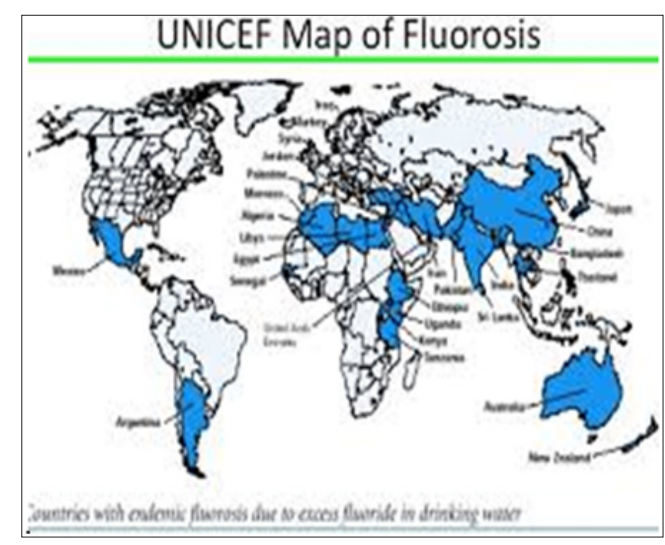

Figure 1: Endemic dental fluorosis worldwide.

Table 1: Diagnostic criteria and weighting system for Dean's Index.

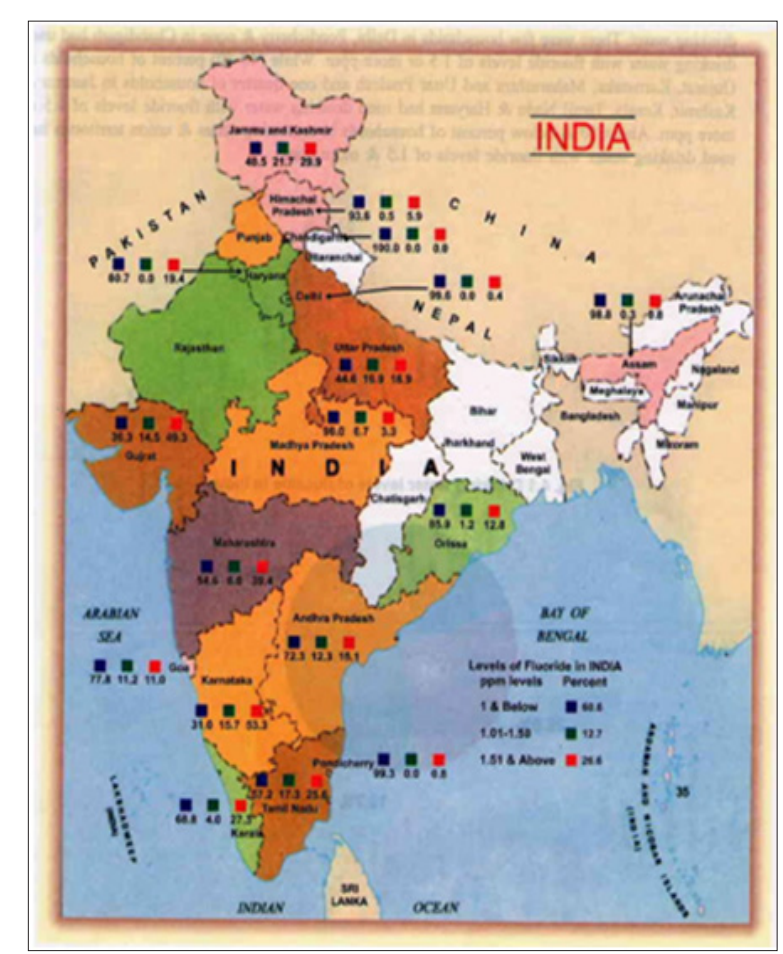

Figure 2: Fluoride concentration in drinking water in the different States of India.

\begin{tabular}{|c|c|c|}
\hline Sl. No. & Classification \& Weighting & Diagnostic Criteria \\
\hline 1 & Normal 0 & $\begin{array}{c}\text { The enamel presents the usual translucent semi-vitreous type of structure. The surface is smooth, glossy, } \\
\text { and usually of a pale creamy white colour. }\end{array}$ \\
\hline 2 & Questionable 0.5 & $\begin{array}{l}\text { The enamel discloses slight aberrations from the translucency of normal enamel, ranging from a few white } \\
\text { flecks to occasional white spots. This classification is utilized in those instances where a definite diagnosis } \\
\text { of the mildest form of fluorosis is not warranted and a classification of "normal" not justified }\end{array}$ \\
\hline 3 & Very mild 1 & $\begin{array}{l}\text { Small, opaque, paper-white areas scattered irregularly over the tooth but not involving as much as } \\
\text { approximately } 25 \% \text { of the tooth surface. Frequently included in this classification are teeth showing no } \\
\text { more than about } 1-2 \mathrm{~mm} \text { of white opacity at the tips of the summits of the cusps of the bicuspids or second } \\
\text { molars. }\end{array}$ \\
\hline 4 & Mild 2 & $\begin{array}{c}\text { The white opaque areas in the enamel of the teeth are more extensive but do not involve as much as } 50 \% \\
\text { of the tooth. }\end{array}$ \\
\hline 5 & Moderate 3 & $\begin{array}{c}\text { All enamel surfaces of the teeth are affected, and surfaces subject to attrition show marked wear. Brown } \\
\text { stain is frequently a disfiguring feature }\end{array}$ \\
\hline 6 & Severe 4 & $\begin{array}{l}\text { All enamel surfaces are affected and hypoplasia is so marked that the general form of the tooth may be } \\
\text { affected. The major diagnostic sign of his classification is the discrete or confluent pitting. Brown stains are } \\
\text { widespread, and teeth often present a corroded-like appearance. }\end{array}$ \\
\hline
\end{tabular}

Table 2: Status of Inteligent Quotient (IQ) Level of children at different concentration of fluoride level in drinking water

\begin{tabular}{|c|c|c|c|c|}
\hline Sl. No & Author (Year) & Fluoride Concentration & IQ Level & Ref. No. \\
\hline 1 & Lu (2000) & $3.15 \mathrm{mg} / \mathrm{L}$ & Decrease & 40 \\
\hline 2 & Hong (2001) & $2.85 \mathrm{mg} / \mathrm{L}$ & Decrease & 42 \\
\hline 3 & Wang (2001) & $2.97 \mathrm{mg} / \mathrm{L}$ & Decrease & 43 \\
\hline 4 & Xiang (2003) & $1.9 \mathrm{mg} / \mathrm{L}$ & Decrease & 44 \\
\hline 5 & Seraj (2006) & $2.5 \mathrm{mg} / \mathrm{L}$ & Decrease & 45 \\
\hline 6 & Sudhir KM, et al. (2009) & $0.7-1.2 \mathrm{mg} / \mathrm{L}$ & Decrease & 46 \\
\hline 7 & Ding (2011) & $0.3-3.0 \mathrm{mg} / \mathrm{L}$ & Decrease & 47 \\
\hline 8 & Shivaprakash (2011) & $2.5-3.5 \mathrm{mg} / \mathrm{L}$ & Decrease & 48 \\
\hline 10 & Seraj (2012) & $3.1 \mathrm{mg} / \mathrm{L}$ & Decrease & 49 \\
\hline
\end{tabular}




\begin{tabular}{|c|c|c|c|c|}
\hline 11 & Karimzade (2014) & $3.94 \mathrm{mg} / \mathrm{L}$ & Decrease & 50 \\
\hline 12 & Zhang (2015) & $1.4 \mathrm{mg} / \mathrm{L}$ & Decrease & 51 \\
\hline 13 & Choi (2015) & $2.2 \mathrm{mg} / \mathrm{L}$ & Decrease & 52 \\
\hline 14 & Das $(2016)$ & $2.1 \mathrm{mg} / \mathrm{L}$ & Decrease & 53 \\
\hline 15 & Bashash $(2017)$ & 0.15 to $1.38 \mathrm{mg} / \mathrm{L}$ & Decrease & 54 \\
\hline
\end{tabular}

\section{Classification of Dental Fluorosis}

On the basis of degree of severity of the mottled enamel, which were associated with varying levels of fluoride in the drinking water defects Dean [34] has classified the dental fluorosis into six classes (Tables 1 \& 2).

\section{Pathophysiology}

Dental fluorosis is a sign of fluoride toxicity and can range from very mild to severe. Clinically, it is characterized by staining and pitting of the teeth. In more severe cases, the entire enamel may be damaged and lost. During formative stage, intake of fluoride content drinking water enamel formation is disturbed and ultimately gets hypo-mineralised at its maturation. The prevalence of dental fluorosis is dependent upon the fluoride intake in the early stage of life [35]. The development of fluorosis is also highly dependent on the dose, duration, and timing of fluoride exposure. The risk of enamel fluorosis is lowest when exposure takes place only during the secretory stage, but highest when exposure occurs in both secretory and maturation stages [36]. Enamel is produced by specialized epithelial cells called ameloblasts. The chief function of an ameloblast is to support the growth of a single hydroxyl-apatite enamel rod by secreting scaffold proteins during the secretory stage, in which the rods growth in length, and then removing these proteins during the maturation stage, in which the rods thicken [37]. Fluorosis occurs when fluoride interacts with mineralizing tissues, causing alterations in the mineralization process.

Indentalenamel,fluorosiscausessubsurfacehypomineralization or porosity, which extends toward the dentinal-enamel junction as severity increases. This subsurface porosity is most likely caused by a delay in the hydrolysis and removal of enamel proteins, particularly amelogenins, as the enamel matures. At the early maturation stage, the relative quantity of amelogenin protein is increased in fluorosed enamel in a dose-related manner. This appears to result from a delay in the removal of amelogenins as the enamel matures [38]. Although, definite mechanism of dental flourosis is yet to be confirmed, current knowledge on ameloblast function during enamel formation may help to understand the same. Previously it was demonstrated that fluoride induces phosphorylation of the alpha subunit of eukaryotic initiation factor 2 (eIF $2 \alpha$ ) ribosomal components, which significantly decreases protein synthesis. This occurs during the maturation stage of development when proteins are normally removed from the hardening enamel. Megan et al. have recently hypothesized a potential mechanism in which excess fluoride results in increased protein levels and softened enamel via decreased protease secretion during the maturation stage.

According to them phospho-eIF $2 \alpha$ mediated inhibition of protein production induced by intracellular fluoride results in decreased secretion of the enamel protease kallikrein-4 (KLK4) during the enamel maturation phase. This in turn results in decreased protein breakdown and higher protein content within the enamel matrix [39]. At low concentration fluoride gets incorporated ions into the hydroxyapatite crystals of enamel which increases hardness and reduces demineralization, thereby prevents caries formation. Excess fluoride, however, has a detrimental effect on developing enamel, resulting in opaque mottling, pitting and, in severe cases, makes enamel porous, soft and severely demineralised. The fluorotic enamel are found to be hypomineralized with, increased levels of protein content when compared to the nonfluorosed enamel $[40,41]$.

\section{Fluoride and IQ Level}

Findings evidence that fluoride exposure during the early years of life can damage a child's developing brain. Researchers from different countries have reported that IQ level of the children was seriously affected by water fluoride even at lowest concentration! Almost all the authors have concluded that overall IQ levels in children's exposed to high fluoride level were significantly lower than the low fluoride areas and Children with mild dental fluorosis had lower IQ than those without dental fluorosis [42-55].

\section{Conclusion}

Dental fluorosis is not merely a cosmetic problem but a serious condition that affects the aesthetic, emotional, social, and even psychological aspects of an individual's life. Whatever it may be the source, fluoride has a detrimental effect on teeth enamel leading to premature loss of teeth at large, Furthermore, how does dental fluorosis affect the central nervous system and lower the IQ level among children needs further investigation.

\section{References}

1. Petersen PE (2003) The World Oral Health Report 2003: Continuous improvement of oral health in the 21st century-the approach of the WHO Global Oral Health Programme. Community Dentistry and oral epidemiology 31(1): 3-24.

2. Fluoride and Fluorosis A review report on Fluorosis.

3. Roveri N, Foresti E, Lelli M, Lesci IG (2009) Recent advancements in preventing teeth health hazard: the daily use of hydroxyapatite instead of fluoride. Recent Patents on Biomedical Engineering 2(3): 197-215.

4. Møller IJ, Pindborg JJ, Gedalia I, Roed-Petersen B (1970) Prevalence of dental fluorosis in the people of Uganda. Archives of Oral Biology 15(3): 213-225.

5. Thylstrup A, Fejerskov O (1978) Clinical appearance of dental fluorosis in permanent teeth in relation to histological changes. Community Dentistry and Oral Epidemiology 6(6): 315-328.

6. Olsson B (1979) Dental findings in high-fluoride areas in Ethiopia. Community Dentistry and Oral Epidemiology 7(1): 51-56.

7. Manji F, Bælum V, Fejerskov $O$ (1986) Dental fluorosis in an area with 2 ppm fluoride in drinking water. Journal of Dental Research 65(5): 659662. 
8. Alhobeira HA, Siddiqui AA, Mian RI (2015) Prevalence and Severity of Dental Fluorosis in Hail, Saudi Arabia. Journalof International Oral Health 7(12): 1.

9. Khan N, Al-Zarea B, Al-Mansour M (2001) Dental caries, hygiene, fluorosis and oral health knowledge of primary school teachers of Riyadh, Saudi Arabia. Saudi Dental Journal 13(3):128-132..

10. Mishra AK, Mishra A (2006) Study of quaternary aquifers in Ganga Plain, India. J Hazardous Mat 144(1-2): 438-448.

11. Petersen PE, Kwan S, Zhu L, Zhang BX, Bian JY (2006) Effective use of fluorides in the People's Republic of China - A model for WHO Mega Country initiatives. Community Dental Health 2008 25(1): 257-267.

12. Farooqi A, Masuda H, Firdous N (2007) Toxic fluoride and arsenic contaminated groundwater in the Lahore and Kasur districts, Punjab, Pakistan and possible contaminant sources. Environ Pollut 145(3): 839849.

13. Kaseva ME (2006) Contribution of trona (Magadi) into excessive fluorosis: a case study in Maji ya Chaid ward, northern Tanzania. Total Environ 366: 92-100.

14. Casagranda MP, Knöler K, Roisenberg A (2007) Anomalous fluoride concentration in groundwater: is it natural or pollution? A stable isotope approach, Isotopes in Environ Health Stud 43(2): 165-175.

15. Gaciri SJ, Davies TC (1993) The occurrence and geochemistry of fluoride in some natural waters of Kenya. Journal of Hydrology 143(3-4): 395412.

16. Lung S, Cheng H, Fu CB (2008) Potential exposure and risk of fluoride intakes from tea drinks produced in Taiwan. J Expos Sci Enviro Epidemiol 18(2): 158-166.

17. Msonda KWM, Masamba WRL, Fabiano E (2007) A study fluoride groundwater occurrence in Nathenje. Phys Chem Earth 32(15-18): 1178-1184.

18. Sun DJ, Shen YF, Zhao XH (2001) Analysis on the disease trend and present state of endemic fluorosis in China mainland. Chinese J Ende 20(6): 429-433.

19. Siddiqui AA, Hazza AlH, Mirza AJ, Alshammari AK, Alshammari BA, et al. (2017) Dental Fluorosis in Saudi Arabia: A review of current Literature. Annals of International Medical and Dental Research 3(3): 44-49.

20. Bali RK, Mathur VB, Talwar PP, Channa HB (2004) National Oral Health Survey \& Fluoride Mapping 2002-2003. Dental Council of india, Ministry of Health \& Family Welfare, Government of India.

21. Dean HT, Elvove E (1935) Studies on the minimal threshold of the dental signs of chronic endemic dental fluorosis (mottled enamel). Pub Health Rep 50(49): 1719-1729.

22. Dean HT, Elvove E (1937) Further studies on the minimal threshold of the dental signs of chronic endemic dental fluorosis. Pub Health Rep 52: 1259-1264.

23. Galagan DJ, Lamson GG (1953) Climate and endemic dental fluorosis. Public Health Report 68(5): 497-508, Washington, USA.

24. Richards LF, Westmoreland WW, Tashiro M, McKay CH, Morrison JT (1967) Determining optimum fluoride levels for community water supplies in relation to temperature. Journal of American Dental Association 74(2): 389-397.

25. Warnakulasuriya KAAS, Balasiriya S, Perera PAJ, Peiris LCL (1992) Determining optimal levels of fluoride in drinking water for hot, dry climates - a case study in Sri Lanka. Community Dentistry and Oral Epidemiology 20(6): 364-367.

26. Mabelya L, König KG, van Palenstein Helderman WH (1992) Dental fluorosis, altitude and associated dietary factors. Caries Research 26(1): 65-67.

27. Manji F, Bælum V, Fejerskov O (1986) Fluoride, altitude and dental fluorosis. Caries Research 20(5): 473-480.
28. Han YZ, Zhang JQ Liu XY, Zhang LZ, Yu XH, et al. (1995) High fluoride content of food and endemic fluorosis. Fluoride 28(4): 201-202.

29. Murray MM, Dagmar CW (1948) Fluorosis and nutrition in Morocco: Dental studies in relation to environment. British Dental Journal 84(5): 97-100.

30. Forsman B, Ericsson Y (1973) Fluoride absorption from swallowed fluoride toothpaste. Community Dentistry and Oral Epidemiology 1(3): 115-120.

31. Ekstrand J, Ehrneb M (1980) Absorption of fluoride from fluoride dentifrice. Caries Research 14(2): 96-102.

32. Ekstrand J, Koch, Petersen LG (1983) Plasma fluoride concentrations in preschool children after ingestion of fluoride tablets and toothpaste. Caries Research 17(4): 379-384.

33. Sorce.

34. Dean HT (1934) Classification of mottled enamel diagnosis. J Am Dent Assoc 21(8): 1421-1426.

35. Alvarez JA, Rezende KMPC, Marocho SMS, Alves FBT, Celiberti P, et al. (2009) Dental fluorosis: exposure, prevention and management. Med Oral Patol Oral Cir Bucal 14(2): 103-107.

36. DenBesten PK (1999) Biological mechanisms of dental fluorosis relevant to the use of fluoride supplements. Community Dent Oral Epidemiol 27(1):41-47.

37. Bronckers AL, Lyaruu DM, DenBesten PK (2009) The impact of fluoride on ameloblasts and the mechanisms of enamel fluorosis. J Dent Res 88(10): 877-893.

38. Denbesten P, Li W (2011) Chronic fluoride toxicity: dental fluorosis. Monogr Oral Sci 22: 81-96.

39. Sierant ML, Bartlett JD (2011) A Potential Mechanism for the Development of Dental Fluorosis. In (Eds.) K Sasaki Interface Oral Health Science 408-412.

40. Clarkson JJ, Hardwick K, Barmes D, Richardson LM (2000) International collaborative research on fluoride. J Dent Res 79(4): 893-904.

41. Lu Y, ZR Sun, LN Wu, X Wang, W Lu, et al. (2000) Effect of high-fluoride water on intelligence of children. Fluoride 33(2): 74-78.

42. Hong F, Yanxiang Cao, Hui Wangb (2001) Research on the effects of fluoride on child intellectual development under different environmental conditions. Chinese Primary Health Care 15(3): 56-57 (republished in Fluoride 2008 41(2):156-60).

43. Wang X, Xiu--hong, WANG, Ling-fang, HU, et al. (2001) Effects of high iodine and high fluorine on children's intelligence and thyroid function. Chinese Journal of Endemiology 20(4): 288-290.

44. Xiang Q, Y Liang, L Chen, C Wang, B Chen, et al. (2003) Effect of fluoride in drinking water on children's intelligence. Fluoride 36(2): 84-94.

45. Seraj B, Shahrabi M, Falahzade M, Falahzade F, Akhondi N, et al. (2006) Effect of high fluoride concentration in drinking water on children's intelligence. Journal of Dental Medicine 19(2): 80-86.

46. Sudhir KM, Chandu GN, Prashant GM, Subba VV, Reddy (2009) Effect of fluoride exposure on intelligence quotient (IQ) among 13-15 year old school children of known endemic area of fluorosis, Nalgonda District, Andhra Pradesh. Journal of the Indian Association of Public Health Dentistry 13: 88-94.

47. Ding Y, YanhuiGao, Sun H, Han H, Wang W, et al. (2011) The relationships between low levels of urine fluoride on children's intelligence, dental fluorosis in endemic fluorosis areas in Hulunbuir, Inner Mongolia, China. Journal of Hazardous Materials 186(2-3): 1942-1946.

48. Shivaprakash PK, Ohri K, Noorani H (2011) Relation between dental fluorosis and intelligence quotient in school children of Bagalkot district. J Indian Soc Pedod Prev Dent 29(2):117-120. 
49. Seraj B, Shahrabi M, Shadfar M, Ahmadi R, Fallahzadeh M, et al (2012) Effect of high water fluoride concentration on the intellectual development of children in Makoo/Iran. Journal of Dentistry, Tehran University of Medical Sciences 9(3): 221-29.

50. Nagarajappa R, Pujara P, Sharda AJ, Asawa K, Tak M, et al. (2013) Comparative assessment of intelligence quotient among children living in high and low fluoride areas of Kutch, India: a pilot study. Iranian Journal of Public Health 42(8): 813-818.

51. Karimzade S, M Aghaei, AH Mahvi (2014) Investigation of intelligence quotient in 9-12-year-old children exposed to high- and low-drinking water fluoride in West Azerbaijan province, Iran. Fluorid 47(1): 9-14.

52. Zhang S, Zhang X, Liu H, Qu W, Guan Z, et al. (2015) Modifying Effect of COMT Gene Polymorphism and a Predictive Role for Proteomics Analysis in Children's Intelligence in Endemic Fluorosis Area in Tianjin China. Toxicological Sciences 144(2): 238-245.
53. Choi A, Zhang Y, Sun G, Bellinger DC, Wang K, et al. (2015) Association of lifetime exposure to fluoride and cognitive functions in Chinese children: A pilot study. Neurotoxicology \& Teratology 47: 96-101.

54. Das K, Mondal NK (2016) Dental fluorosis and urinary fluoride concentration as a reflection of fluoride exposure and its impact on IQ level and BMI of children of Laxmisagar, Simlapal Block of Bankura District, W.B., India. Environmental Monitoring \& Assessment 188(4): 21-28.

55. Bashash M, Thomas D, Hu H, Angeles Martinez-Mier E, Sanchez BN, ET AL. (2017) Prenatal Fluoride Exposure and Cognitive Outcomes in Children at 4 and 6-12 Years of Age in Mexico. Environmental Health Perspectives 125(9): 097017

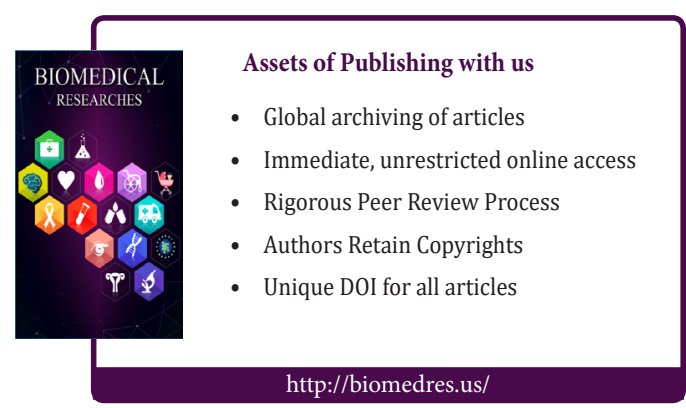

